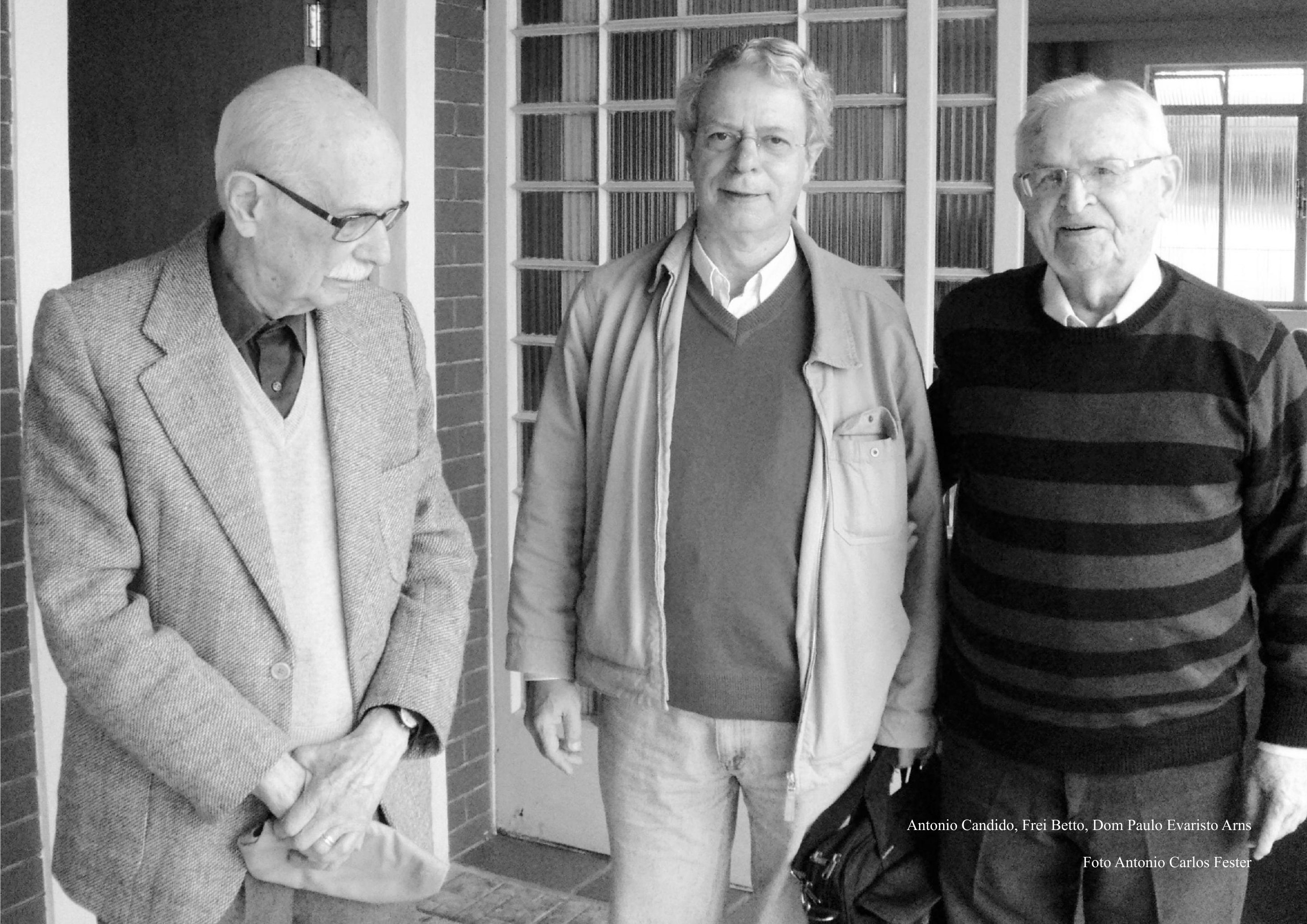




\title{
Antonio Candido militante
}

\author{
Frei Betto*
}

Sabemos todos que Antonio Candido se destaca entre os mais qualificados críticos literários da história do Brasil e merece figurar entre os mais eminentes sociólogos. Porém, sua longa trajetória de vida foi marcada também pela militância política. Esse carioca de temperamento e hábitos mineiros, fala ponderada e gestos comedidos, gentleman da intelectualidade, fino no físico e no trato, se sobressai como exemplo de coerência de princípios éticos, humanitários.

Antonio Candido iniciou a sua militância política na década de 1940, quando se filiou ao Partido Socialista Brasileiro e editou o jornal clandestino Resistência, de oposição à ditadura de Getúlio Vargas. Em fevereiro de 1980, participou da fundação do PT (Partido dos Trabalhadores), ao lado de intelectuais como Sérgio Buarque de Holanda e Paulo Freire.

Fomos amigos. Tivemos poucas, mas memoráveis conversas, em especial à mesa de nossa amiga comum, Adélia Bezerra de Meneses. Ele e eu, amigos de Lula, estávamos ligados ao PT. A diferença é que minha vinculação sempre foi a de simpatizante. Ao contrário dele, nunca me filiei a partidos políticos. Antonio Candido aderiu, como filiado e militante, à proposta de Lula por considerá-la oposta à "vanguarda iluminada", como se expressou em crítica ao dogmatismo stalinista.

* Frei Betto é escritor, autor de Por uma educação crítica e participativa (Rocco), entre outros livros. Site: www.freibetto.org 
Socialista convicto, declarou aos 93 anos de idade:

O socialismo é uma doutrina totalmente triunfante no mundo. E não é paradoxo. O que é o socialismo? É o irmão-gêmeo do capitalismo, nasceram juntos, na revolução industrial. É indescritível o que era a indústria no começo. Os operários ingleses dormiam debaixo da máquina e eram acordados de madrugada com o chicote do contramestre. Isso era a indústria. Aí começou a aparecer o socialismo. Chamo de socialismo todas as tendências que dizem que o homem tem que caminhar para a igualdade, ele é o criador de riquezas e não pode ser explorado. Comunismo, socialismo democrático, anarquismo, solidarismo, cristianismo social, cooperativismo... tudo isso. Esse pessoal começou a lutar para o operário não ser mais chicoteado; depois, para não trabalhar mais que doze horas; depois, para não trabalhar mais que dez, oito; para a mulher grávida não ter que trabalhar; para os trabalhadores terem férias; para ter escola para as crianças. Coisas que hoje são banais. Conversando com um antigo aluno meu, que é um rapaz rico, industrial, ele disse: "O senhor não pode negar que o capitalismo tem uma face humana." O capitalismo não tem face humana nenhuma. O capitalismo é baseado na maisvalia e no exército de reserva, como Marx definiu. É preciso ter sempre miseráveis para tirar o excesso que o capital precisa. E a mais-valia não tem limite. Marx diz em A Ideologia Alemã: as necessidades humanas são cumulativas e irreversíveis. Quando você anda descalço, você anda descalço. Quando você descobre a sandália, não quer mais andar descalço. Quando descobre o sapato, não quer mais a sandália. Quando descobre a meia, quer sapato com meia, e por aí não tem mais fim. E o capitalismo está baseado nisso. O que se pensa que é face humana do capitalismo é o que o socialismo arrancou dele com suor, lágrimas e sangue. Hoje é normal o operário trabalhar oito horas, ter férias... tudo é conquista do socialismo. (Entrevista a Joana Tavares, "O socialismo é uma doutrina triunfante". Brasil de Fato, 8 ago. 2011.) 
Para Antonio Candido - crítico ao socialismo real -, à democracia econômica ali existente (a partilha de bens e a garantia universal de direitos básicos a toda a população, como alimentação, saúde e educação) faltava a contrapartida da democracia política, da efetiva participação popular de condução do processo social. Sem se opor, ele mantinha a devida distância de Lenin e Trotsky, e a convicção de que é preferível correr o risco de errar com a classe trabalhadora do que ter a pretensão de acertar sem ela.

Antonio Candido era homem de base, aliado ao MST (Movimento dos Trabalhadores Rurais Sem Terra), malgrado seu porte refinado, mas um refinamento antiburguês, de quem não abre a guarda a meros interesses mercantilistas. Senhor de suas emoções, sabia escutar quem se lhe opunha ideologicamente sem jamais perder a fleuma. Não se deixava levar por essa ansiedade de querer catequizar o adversário e convencê-lo de seu equívoco. No calor do debate, preservava-se em altivo e respeitoso silêncio. Indagado, expressava seu ponto de vista com firme moderação. Sabia ser etimologicamente humilde (húmus, terra), pés no chão e altura própria, nem menor nem maior.

Em 2002, Antonio Candido teve a gentileza de redigir a apresentação de meu livro sobre Lula, destinado à campanha presidencial daquele ano. No texto, ressalta Lula como

o líder operário que contribuiu decisivamente para imprimir novo rumo à vida política brasileira, ao consagrar a entrada do trabalhador na linha de frente das decisões nacionais, quebrando a tendência de manipulálo segundo fórmulas ideológicas pré-fabricadas ou de acordo com os interesses das classes dominantes. O leitor poderá verificar como Lula está no centro desse grande movimento histórico, que mudará a fisionomia e a estrutura da sociedade brasileira. De fato, ele encarna de maneira exemplar as aspirações de sua classe, desde 
o momento em que deu alma nova ao movimento sindical, esforçando-se para situá-lo na vanguarda da luta pela democracia. Ao fazer isso, firmou-se cada vez mais como homem representativo, como porta-voz, não como um desses dirigentes revestidos de autoritarismo mágico, que tentam impor a própria personalidade. A mola dos seus atos são os interesses legítimos da classe trabalhadora, que contém mais do que qualquer outra os germes da transformação pela qual a sociedade deve passar, a fim de pôr termo à situação insuportável de miséria e iniquidade que caracteriza o Brasil de hoje. Por isso, do movimento sindical por ele dirigido saiu logicamente o Partido dos Trabalhadores, que se impõe a cada dia pela capacidade de abrir os trilhos do futuro, em marcha pelo socialismo. (Lula, um operário na Presidência, São Paulo, Casa Amarela, 2002).

Antonio Candido era ateu convicto, porém desprovido de qualquer proselitismo. Entre seus melhores amigos figuravam meu confrade, o dominicano frei Benevenuto de Santa Cruz, meu professor de ética e diretor da Livraria e Editora Duas Cidades, tão frequentada por Antonio Candido. Contou-me que frei Benevenuto fazia parte de sua família, e, quando foram juntos a Porto Alegre, nos anos 50, nos restaurantes todos miravam espantados aquele homem de hábito branco, pois não havia frade dominicano no Sul do país. Benevenuto está enterrado no túmulo da família de Antonio Candido.

Manteve também profundo vínculo com o cardeal Dom Paulo Evaristo Arns, arcebispo de São Paulo e figura de destaque na oposição à ditadura militar. Por isso, não relutou ao ser convidado para integrar a Comissão de Justiça e Paz da Arquidiocese de São Paulo.

Na segunda-feira, 12 de setembro de 2011, em companhia de Antonio Carlos Ribeiro Fester, apanhei Antonio Candido à porta do prédio onde morava, na Alameda Joaquim Eugenio de 
Lima, em São Paulo. Aos 93 anos, desceu lépido as escadas. Fomos visitar Dom Paulo Evaristo Arns em seu retiro, em Taboão da Serra. No percurso, Antonio Candido comentou ter lido meu romance histórico Minas do Ouro (Rio, Rocco, 2011). Elogiou capítulos e criticou o anacronismo de alguns nomes próprios.

No dia seguinte, ele faria conferência no IEB (Instituto de Estudos Brasileiros) sobre Sérgio Buarque de Holanda. Queixouse ter sido convidado para "uma mesa", e agora se dava conta de que não tinha parceiro, seria o único a falar... Lembrei que a mim também acontecia de anunciarem meu nome em palestras e eventos para os quais nem havia sido convidado...

Recordou ter participado da festa dos 60 anos de idade de Sergio Buarque de Holanda. E eu, dos 70, na casa do Chico Buarque, no Rio, quando Sérgio cantou a famosa marchinha de carnaval "Sassaricando", em latim. Antonio Candido, senhor de uma memória prodigiosa, recitou a letra no carro... Lembrou ainda da música que os filhos de Sérgio fizeram para os seus 60 anos - "não é um velho coroca/ é um rapaz bem capaz" - e cantou a letra completa. Recitou ainda todo o primeiro verso do "Primeiro Canto", de Camões, miniespectáculo desfrutado apenas por dois espectadores, Fester e eu.

Contou que nascera no Rio e, aos oito meses de idade, a família se mudara para Santa Rita de Cássia, em Minas, na época distrito do município de Passos, onde seu pai se estabeleceu como médico. Mas a sua cidade do coração, observou, era Poços de Caldas, que também encantava sua mãe. A família morou ali até 1992, quando a casa foi vendida.

Dom Paulo Evaristo Arns nos recebeu falante. Completara 90 anos a 14 de setembro de 2011.

Como explicar o perene frescor do pensamento de Antonio Candido? Não tende a militância petrificar a visão? E o exercício 
do magistério, sobretudo catedrático, não fomenta certa arrogância, suscitando aquele tom de quem, do alto da torre, julga ver melhor do que os outros?

Minha opinião é que o espírito tão democrático de Antonio Candido, sua sincera entrega à alteridade, se deveu ao seu trato com a literatura de ficção. A ficção é a realidade em forma de sonhos. Como ensinou Aristóteles, ela não precisa ser verdadeira, e sim verossímil. E quando se transita no mundo da arte, no qual se situa a literatura de ficção, corre-se menos risco de se deixar contaminar por dogmas, ortofonias, ideias petrificadas. Porque o artista é, por excelência, abridor de janelas, demolidor de paredes, alargador de caminhos, amante de horizontes infindos. Para ele não basta o agora. Ele busca também o além. E na literatura seu único limite é o da impossibilidade da palavra. E para ele palavra não se resume a vocábulo. Nisto o artista concorda com o evangelista João, é preciso que o verbo se faça carne. E em Antonio Candido todo o seu discurso resultava da coerência ética de sua prática. 